Vol. 2 No. 2

December 2020

e- ISSN 2685 - 0559

p- ISSN $2684-673 X$

\title{
THE STRUGGLE TO AGAINST PATRIARCHAL DOMINANCE IN ROMEO AND JULIET DRAMA
}

\author{
Sri Sinta \\ Universitas Putera Batam, Batam Indonesia \\ markabansinta@gmail.com \\ Ambalegin \\ Universitas Putera Batam, Batam Indonesia \\ Abhi140475@gmail.com
}

\begin{abstract}
This research aimed to find out the form of Juliet's struggle against patriarchal dominance in a drama under the title Romeo and Juliet. The research was a descriptive qualitative research. The theory of feminism belonged to Simone de Beauvoir and Sylvia Walby to find out the patriarchal dominance. The results of this study indicated that women at that time were only seen as objects in patriarchal societies which placed the position of men, especially fathers as leaders and decision makers. This condition had an impact on limiting women's space and rights so that they unconsciously submitted and accepted it as something normal. Juliet was also a victim of male masculine dominance. She was an object to be exchanged in marriage and objects contested by men. Juliet's form of resistance also varied from making excuses for not getting married, eloping with Romeo and leaving her family, to drink the potion given by Friar Lawrence.
\end{abstract}

Keywords: feminism, patriarchy, Shakespeare's Romeo and Juliet

\section{INTRODUCTION}

At the end of the 16th century, the Elizabethan's period, the patriarchal culture was very protruding. Men dominated women especially in the household. The role of father in ancient times until now is very influenced. This happened in the scope of father's responsibility to his daughters. This is considered as the patriarchal culture. In this case the father's strength was very visible, thus affecting the position of a woman. This cultural system was spread from generation to generation that organize the women's status within men. In society, this made the status and position of women very sorrowful. Women were assumed secondary in all fields and always oppressed. This patriarchal circumstances which brought forth to several shapes of discrimination against women which progressively 
Vol. 2 No. 2

December 2020

e- ISSN 2685 - 0559

p- ISSN 2684 - 673X

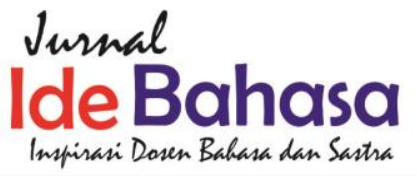

asserted the men's status in society (Das, 2012).

Patriarchal women are women who unwittingly received patriarchal norms and graded as a culture that prerogatives men by giving traditional gender roles (Tyson, 2006). Patriarchal culture was not only illustrated in a real life, but it was also reflected in several literary works. Given that of William Shakespeare's literary work, he wrote his workart by looking at the picture of life at that time. Romeo and Juliet are Shakespeare's famous plays. In the play there was an element of patriarchy in which men dominated against women. This was seen by the figure of a father to his daughter, Juliet. Juliet was also betrothed by his father's choice, but Juliet opposed his father's rules. Therefore, the role of men was in a big portion, especially in household areas.

de Beauvoir (1986) stated that man was a subject and woman was object or other. This was seen by the main character of Juliet. Juliet was categorized as an object because she was another figure, the second figure of a man. Whereas a man became a subject, he had more power than women. But in this case, Juliet also opposed her father with her refusing an arranged marriage. The dialogue reflected oppression is seen below.

SAMPSON True; and therefore women, being the

weaker vessels, are ever thrust to the wall: therefore

I will push Montague's men from the wall, and thrust his

maids to the wall. $(I, I, 18-21)$

the statement shows men looked down on female maids from the Montague family. Women were considered inferior and oppressed, especially among women who worked as servants. This was getting worse when facing women who came from the families of their arch enemy. The oppression experienced by women at that time was caused by the assumption in patriarchal society that women were property owned by the head of the family. That referred to the patriarchal society, the environment in which women were subject to the rules made by men and women were considered as a second sex (de Beauvoir, 1986).

This article compared some previous articles to show how important investigating this phenomenon. Avei (2006) discussed two major examples of stories based on the theme of forbidden love. The focus of this study is the love stories of Romeo and Juliet, and Layla and Majnun. While Romeo and Juliet is one of the greatest examples of this theme in Western Literature, the story of Layla and Majnun is one of the most significant expressions of this theme in Old Turkish Literature.

Jajja (2014) found some problems in Shakespeare's drama (Hamlet, Macbeth, King Lear, Antony and Cleopatra, Romeo and Juliet), the problem was seen from the woman who was oppressed by the man from patriarchal perspective. The results of the research were that women in Shakespearean tragedies were portrayed as lesser negative stereotypes. These texts had reinforced and strengthened the patriarchal values.

The position of men and women in drama also has a connection with the 
Vol. 2 No. 2

December 2020

e- ISSN 2685 - 0559

p- ISSN 2684 - 673X

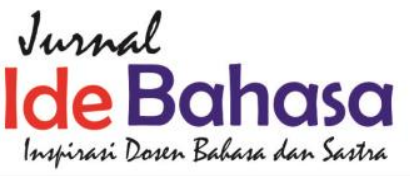

conditions of the society who adopt a patriarchal system. Therefore, this study concerned to the Women in Verona as an object and Juliet's opposition in patriarchal dominance. This study applied the feminist approach. Feminism is a freedom, equality, and justice obtained by women to get their rights. Forms of equality, justice and freedom existed in several environments such as the political environment and others (Cameron, 2018). Feminism is political views that has equality, it is committed to addressing social inequalities relating to gender and sexuality using a series of theories and methodologies (Bucholtz, 2014).

\section{PATRIARCHY}

Patriarchy as a form of power relations where all women's interests are inferior to men's interests. This power relation can be in the form of division of labor based on sex and various social institutions that instill feminine values in community life (Jenainati \& Groves, 2007).

The patriarchal cultural values that develop in society increasingly perpetuate the form of male domination over women. This condition makes women seen as an object, passive, emotional, and spiritual. Women are required to have high moral values and are expected to build good households. Furthermore, they are also required to be "ideal" women who meet the standards set by the society at that time (Tyson, 2003).

women are required to be good daughters for their fathers, and obedient wives for their husbands, and mothers who must be able to take care for their children. This image of women shows how strong the patriarchal system is in social communities. This situation has been going on for centuries with the position of unequal relations between women and men.

According to Tyson (2006), women who lives in a patriarchal social system will automatically adopt patriarchal norms and values as a culture that privileges men by promoting traditional gender roles. These traditional gender roles consider men to be rational, strong, protective and decisive; while women as emotional, weak, nurturing, and submissive creatures. The role of a man who dominates women's lives is the term of patriarchy (de Beauvoir, 1986).

Simone de Beauvoir (1986) described two forms of patriarchal society are man as a subject and woman as an object or other. And Sylvia Walby (1990) described the into two forms of patriarchal society which are private patriarchy and public patriarchy.

\section{METHOD OF THE RESEARCH}

This research was a descriptive qualitative research. The method of collecting data used observation method proposed by Sugiyono (2013). The most important process in collecting the data was observing and remembering which aimed to obtain the description of the discussion directly on the object of research being studied (Sugiyono, 2013). Note-taking technique proposed by Sugiyono (2013) was conducted to get the data. This research applied content analysis as method of analyzing in in literature term proposed by Ratna (2012). This descriptive analysis was done by describing the facts by means of interpretation. Thus, the method of analyzing the data was interpreting technique (Ratna, 2012) 


\section{RESULT AND DISCUSSION}

A. RESULT

1. Woman in Verona as an object of social tradition

Juliet as an object in many ways,

a. Juliet as an exchange in marriage

b. Juliet was not included in marriage decision making

c. Not only Juliet, but the women in Verona were also made objects by degrading methods such as servants' positions and Rosaline was discussed by men aimed at marrying

2. Juliet opposed patriarchal dominance

Juliet's struggle to oppose patriarchal domination such as

a. Delaying the marriage

b. Making excuses for not getting married

c. Eloping with Romeo and leaving her family

d. Drinking the potion given by Friar Lawrence

\section{B. DISCUSSION}

\section{A Woman as an object}

Data 1

SAMPSON. A dog of that house shall move me to stand:

I will take the wall of any man or maid of Montague's.

GREGORY. ${ }^{1}$ That shows thee a weak slave; for the weakest

goes to the wall.

SAMPSON. True; and therefore

women, being the

weaker vessels, are ever thrust to

the wall: therefore I

will push montague's men from the wall, and thrust his maids to the wall. (I.I. 15-20)

The dialog shows the presumption aimed at female maids in the Montague family. Gregory pointed out that female maids were weak slaves. Then Sampson asserted that women including servants were weak creatures. This was revealed especially because they hated people who came from the Montague family and especially, they wanted to show their superiority compared to women from the Montague family. They said that if they would meet men and maids of Montague, they would punish all of them. The next evidence of women as the object was shown by Romeo when describing a woman who made him fallen to Benvolio.

Data 2

ROMEO Well, in that hit you miss:

${ }^{2}$ she'll not be hit

With Cupid's arrow; she hath

Dian's wit;

And, in strong proof of chastity well arm'd,

From love's weak childish bow she lives unharm'd.

She will not stay the siege of loving terms,

Nor bide the encounter of assailing eyes,

Nor ope her lap to saint-seducing gold:

0 , she is rich in beauty, only poor, That when she dies with beauty dies her store.

BENVOLIO Then she hath sworn

that she will still live chaste?

ROMEO She hath, and in that sparing makes huge waste,

For beauty starved with her severity

Cuts beauty off from all posterity. 
Vol. 2 No. 2

December 2020

e- ISSN 2685 - 0559

p- ISSN 2684 - 673X

She is too fair, too wise, wisely too

fair,

To merit bliss by making me

despair:

She hath forsworn to love, and in

that vow

Do I live dead that live to tell it

now. (I.I. 240-257)

During the conversation, Romeo explained to

Benvolio about the woman he was admiring. In the conversation, Romeo described that Rosaline was a woman who had never known love, had a different intelligence than women in general, even vowed to keep her chastity from men who wanted her. This was further reinforced by Romeo's answer when Benvolio asked about Juliet's chastity. Romeo, who was in love with Rosaline, of course considered Rosaline more than any other woman. Moreover, the dialogue above described Rosaline through the views of others.

Data 3

ROMEO ${ }^{3}$ Tis the way To call hers exquisite, in question more:

These happy masks that kiss fair ladies' brows

Being black put us in mind they hide the fair;

He that is strucken blind cannot forget

The precious treasure of his evesight lost:

Show me a mistress that is passing

fair,

What doth her beauty serve, but as a note

Where I may read who pass'd that passing fair?

Farewell: thou canst not teach me to forget (I.I. 262-272)
The dialogue shows how Romeo described the woman he admired, Rosaline. Romeo told Benvolio that Rosaline is "exquisite" that he really wanted it like having a treasure. Romeo also told Benvolio that he was unable to turn to other women instead of Rosaline. This was because Rosaline was considered the most special woman for him, and made him wanted to get her. Even Romeo questioned Benvolio to show other women who were far better than Rosaline in when Benvolio said "Show me a mistress...." On that question, Benvolio did not give a direct answer so Romeo said that if there were no other women who could make him forget Juliet, then he would never be able to forget her.

Data 4

CAPULET But saying o'er what I have said before:

${ }^{4} \mathrm{My}$ child is yet a stranger in the world;

She hath not seen the change of fourteen years;

Let two more summers wither in their pride, Ere we may think her ripe to be a bride. (I.II. 8-12)

The dialogue shows that Capulet believed his daughter was not enough to get married. This was because Paris asked Capulet to marry Juliet who was still too young for her father. It could be seen when Capulet said. Besides, Capulet really understood the nature of his daughter and he was afraid that if she could not maintain the responsibility of the marriage with Paris. Juliet also did not include in this arranged marriage. Therefore, in the conversation Capulet said his daughter was not yet 14 years old and begged to wait around two or more summers when Juliet 
Vol. 2 No. 2

December 2020

e- ISSN 2685 - 0559

p- ISSN 2684 - 673X

grew up and ready to be married without Juliet's knowing.

Data 5

CAPULET And too soon marr'd are those so early made.

The earth hath swallow'd all my hopes but she,

She is the hopeful lady of my earth:

${ }^{5}$ But woo her, gentle Paris, get her

heart,

My will to her consent is but a part;

An she agree, within her scope of

choice

Lies my consent and fair according

voice. ...

Among fresh female buds shall you

this night

Inherit at my house; hear all, all

see,

And like her most whose merit

most shall be:

Which on more view, of many mine

\section{being one}

May stand in number, though in reckoning none,

Come, go with me. (I.II. 14-35)

Capulet and Paris showed the father's form of control over his daughter in marriage. A father could determine whether or not his daughter was married even though she was fourteen years old. Even though Capulet was initially hesitant about Juliet's young marriage, he gave Paris the choice if he wanted to marry his daughter then won his heart. Then Capulet invited Paris to take part in a celebration party held by Capulet so that Paris could easily get to know and approach Juliet. In the dialogue, "Inherit at my house" showed again the form of a father's control of his daughter where Capulet boasted Juliet's figure with the women in the Capulet family.
The form of objectification on women is also found in the conversation between Benvolio and Romeo in the following dialogue.

Data 6

BENVOLIO At this same ancient feast of Capulet's

Sups the fair Rosaline whom thou so lovest,

${ }^{6}$ With all the admired beauties of Verona:

Go thither; and, with unattainted eye,

Compare her face with some that I shall show,

And I will make thee think thy swan

a crow. (I.II. 94-99)

Romeo who was falling in love with a woman suddenly turns into a different man. This was also felt by Benvolio, Romeo's cousin. Benvolio wanted to show Romeo that the woman Romeo admired was not comparable to the woman he admired. Benvolio also said Romeo that in Verona there were a lot of women with definitions of beauty and he also told Romeo to compare the beauty of these women to the woman that Romeo admires.

Data 7

ROMEO When the devout religion of mine eye

Maintains such falsehood, then turn tears to fires;

And these, who often drown'd could never die,

Transparent heretics, be burnt for liars!

${ }^{7}$ One fairer than my love! the allseeing sun

Ne'er saw her match since first the world begun. (I.II. 76-81) 
Vol. 2 No. 2

December 2020

e- ISSN 2685 - 0559

p- ISSN 2684 - 673X

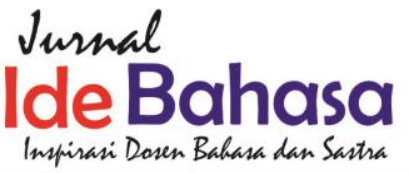

During the conversation, Romeo still insisted that Rosaline was better than other women. He wanted to prove to Benvolio that he believed in Rosaline's beauty. This was revealed to convince Benvolio that he was not wrong to say about Rosaline's beauty. Romeo greatly glorifies Rosaline's beauty before Benvolio. According to him, if the lie to Rosaline's beauty was the same as sin for someone who was lying, the liar would be burned.

\section{Data 8}

BENVOLIO ${ }^{8}$ Tut, you saw her fair, none else being by,

Herself poised with herself in either eye:

But in that crystal scales let there be weigh'd

Your lady's love against some other maid

That I will show you shining at this feast,

And she shall scant show well that now shows best.

ROMEO I'll go along, no such sight

to be shown,

But to rejoice in splendor of mine own. (I.II. 106-113)

Meanwhile, Benvolio said that Romeo's opinion about Rosaline's beauty was only limited to his subjective argument. Without being based on the recognition of others, Romeo's opinion would never be proven. Therefore, Benvolio also wanted to bet on the beauty of Rosaline with other women that he wanted to show. In a party held by Capulet, both would prove who the most beautiful women in Verona was.

\section{Juliet's struggle opposed patriarchal dominance \\ Data 9}

NURSE Peace, I have done. God mark thee to his grace!

Thou wast the prettiest babe that e'er I nursed:

${ }^{9}$ An I might live to see thee married once, I have my wish.

LADY CAPULET Marry, that "marry" is the very theme

I came to talk of. Tell me, daughter Juliet, How stands your disposition to be married? JULIET It is an honour that I dream not of. (I.III.69-76)

The dialogue shows the beginning of Juliet's arranged marriage. The dialogue involved Juliet, the nurse, and Lady Capulet as Juliet's mother who offered if Juliet was interested in marrying a man with a family acquaintance. Lady Capulet wanted to talk about marriage with Juliet whom she had never dreamed of. Her mother's decision was also supported by her nurse that she wished to see Juliet's marriage.

Data 10

NURSE An honour! were not I thine only nurse, I would say thou hadst suck'd wisdom from thy teat.

LADY CAPULET ${ }^{10}$ Well, think of marriage now;

younger

than you,

Here in Verona, ladies of esteem,

Are made already mothers: by my count, I was your mother much upon these years That you are now a maid. Thus then in brief: The valiant Paris seeks you for his love. (I.III.7785)

The dialogue showed the patriarchal society's expectations of women. The nurse also said that it was an honor for a woman of Juliet's age to be married. Lady Capulet also said that women in Verona are ladies of esteem who also many of them have become mothers. In addition, she also said that she wanted Juliet to start thinking about marriage at a young age and offered men who also wanted to marry Juliet. 
Vol. 2 No. 2

December 2020

e- ISSN 2685 - 0559

p- ISSN 2684 - 673X

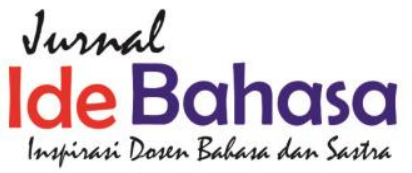

The dialogue above shows that the position of women in this drama remained as an object which was numbered two. What Lady Capulet showed that she was also a woman who was hegemony by patriarchal culture. Moreover, Juliet's position as a daughter in the Capulet family was expected to follow what the head of the Capulet family wanted to marry Juliet.

Data 11

LADY CAPULET ${ }^{11}$ What say you? can you love the gentleman?

This night you shall behold him at our feast;

Read o'er the volume of young Paris' face,

And find delight writ there with beauty's pen;

Examine every married lineament,

And see how one another lends content

And what obscured in this fair volume lies

Find written in the margent of his eyes.

This precious book of love, this unbound lover,

To beautify him, only lacks a cover:

The fish lives in the sea, and 'tis much pride

For fair without the fair within to hide:

That book in many's eyes doth share the glory,

That in gold clasps locks in the golden story;

So shall you share all that he doth possess,

By having him, making yourself no less. (I.III.91-

107)

Hearing Juliet's refusal, Lady Capulet showed the form of her request in a wise manner. This was done to help her husband who also tried to convince the prospective husband of his daughter. Lady Capulet could do this because she used to be the same as Juliet so she could give advice to meet her prospective partners before giving a judgement. Lady Capulet gave some suggestions that Juliet could use to assess the man who would be her future husband. Some of them like looking at a partner's face and finding out what's special about him, from the conversation, and from the eyes.

Data 12
NURSE No less! nay, bigger; women grow by men.

LADY CAPULET ${ }^{12}$ Speak briefly, can you like of

Paris' love? (I.III.108-109)

From the dialogue, Lady Capulet asked Juliet to love Paris when she first met in the banquet held by the Capulet. Her mother said that before refusing a marriage request, it was better to meet and see what Paris was like. Because by meeting face to face, Juliet would know firsthand the sincerity and honesty of Paris who wanted to marry her. Moreover, Lady Capulet also said that by marrying her, Juliet would not feel less because Paris would make her life whole. The nurse also argued that married women will be no less because women grow together with the men who accompany them.

Data 13

JULIET ${ }^{13}$ I'll look to like, if looking liking move:

But no more deep will I endart mine eye Than your consent gives strength to make it fly. (I.III.110-112)

However, Juliet had a reason for not to accept the request of her mother. She tried to obey her mother's request to meet and judge the future husband of her parent's choice. Such refusal was shown by Juliet. This shown how patriarchal environment has been against by Juliet.

At a party held for generations by the Capulet family, Juliet was expected to have the opportunity to get to know Paris more. Capulet had also told Paris that this party was the first step to take Juliet's heart as Lady Capulet also tried to persuade Juliet to accept Paris as well. However, in the party, Juliet was met by Romeo who came wearing a mask. The meeting then made them often meet secretly to treat their longing. But both of them were aware that their family name 
Vol. 2 No. 2

December 2020

e- ISSN 2685 - 0559

p- ISSN 2684 - 673X

on their name would never be able to unite their love. Therefore, both of them think of throwing away their family names if they wanted to unite their love forever.

\section{Data 14}

JULIET O Romeo, Romeo! wherefore art thou

Romeo?

${ }^{14}$ Deny thy father and refuse thy name;

Or, if thou wilt not, be but sworn my love,

And I'll no longer be a Capulet. (II.II.37-40)

Juliet would decide to leave the family name, Capulet, if Romeo also did the same to unite their love. According to Juliet, it was the family name that caused them could not be united because of the war between the two families. The feud that occurred between their families was caused by their two fathers who later influenced anyone in the family environment. That was what caused Juliet to decide to leave her family name together with Romeo. The family's last name made them look at each other as eternal enemies not as partners who love each other.

\section{Data 15}

JULIET ${ }^{15}$, Tis but thy name that is my enemy;

Thou art thyself, though not a Montague.

What's Montague? it is nor hand, nor foot, Nor arm, nor face, nor any other part

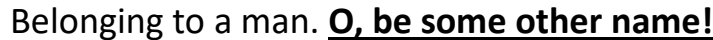
What's in a name? that which we call a rose By any other name would smell as sweet; So Romeo would, were he not Romeo call'd, Retain that dear perfection which he owes Without that title. Romeo, doff thy name, And for that name which is no part of thee

Take all myself. (II.II.43-54)

In the dialogue, Juliet said that it was their surname that caused them to be united, Montague was a family name that was considered illegitimate to the Capulet family, as well as Capulet, a name that people in the Montague family hate. The feud between the two families has an influence on the next generations to continue to hate each other and be hostile without knowing the cause of hostility. For that reason, Juliet took the initiative to leave her family name only to be accepted by Romeo, and vice versa Romeo had to leave Montague's name. For Juliet, Montague did not mean anything, it was not a part of something, the name belongs to someone Romeo must use because it was part of the surname.

Data 16

JULIET Three words, dear Romeo, and good night indeed.

If that thy bent of love be honourable,

${ }^{16}$ Thy purpose marriage, send me word to-morrow,

By one that I'll procure to come to thee,

Where and what time thou wilt perform the rite;

And all my fortunes at thy foot I'll

lay

And follow thee my lord throughout the world.

(II.II.160-167)

In the conversation, Juliet offered Romeo to immediately marry her and determined when the right time and place was. This was done by Juliet because of the pressure she felt from the people around her who wanted Juliet to marry Paris, a man she did not love. However, what was planned by Juliet did not take place easily because of the pressure from the surroundings. From some of the responses shown by Juliet, she increasingly emphasized that she consciously opposed what was determined by her parents. From the beginning it was only reasonable not to get married.

Data 17 
Vol. 2 No. 2

December 2020

e- ISSN 2685 - 0559

p- ISSN 2684 - 673X

CAPULET God's bread! it makes me mad:

Day, night, hour, tide, time, work, play,

Alone, in company, still my care hath been

To have her match'd: and having now provided

A gentleman of noble parentage, Of fair demesnes, youthful, and nobly train'd,

Stuff'd, as they say, with honourable parts,

Proportion'd as one's thought would wish a man;

And then to have a wretched puling fool,

A whining mammet, in her fortune's tender,

To answer ${ }^{17}$ “I'll not wed; I cannot love,

I am too young; I pray you, pardon me."

But, as you will not wed, l'll pardon you:

Graze where you will you shall not house with me:

Look to't, think on't, I do not use to jest.

Thursday is near; lay hand on heart, advise:

An you be mine, l'll give you to my friend;

And you be not, hang, beg, starve, die in

the streets,

For, by my soul, I'll ne'er acknowledge thee,

Nor what is mine shall never do thee good:

Trust to't, bethink you; I'll not be forsworn. (III.V.210-231)
The excerpt of the conversation above shows Capulet's anger towards Juliet who disobeyed. According to Capulet, what he had done so far was for the good of Juliet, including marrying him to the man of his choice. From that reason, we could find out that there was a purpose why Juliet was married to Paris, because of her status and class. Capulet did not want Juliet to marry an ordinary man or even someone who was considered as his sworn enemy. He also recalled some of the reasons Juliet used to postpone his marriage to Paris.

Data 18

CAPULET Sir Paris, I will make a desperate tender

Of my child's love: ${ }^{18}$ I think she will be ruled

In all respects by me; nay, more, I doubt it not.

Wife, go you to her ere you go to bed;

Acquaint her here of my son Paris' love;

And bid her, mark you me, on Wednesday next-

But, soft! what day is this?

PARIS Monday, my lord, CAPULET Monday! ha, ha! Well, Wednesday

is too soon,

O' Thursday let it be: o' Thursday, tell her,

She shall be married to this noble earl.

Will you be ready? do you like this haste?

We'll keep no great ado,-a friend or two;

For, hark you, Tybalt being slain so late, 
Vol. 2 No. 2

December 2020

e- ISSN 2685 - 0559

p- ISSN 2684 - 673X

It may be thought we held him carelessly,

Being our kinsman, if we revel much:

Therefore we'll have some half a dozen friends,

And there an end. But what say you to Thursday?

(III.IV.14-32)

The form of a father's power towards his daughter by determining the wedding ceremony schedule immediately without Juliet's knowledge. He felt responsible for what happened in his family, including forcing Juliet to immediately marry Paris. In the dialogue above Capulet told Paris that he had control over his daughter. This was what made Juliet never be free from her father's power, so all she could do just stall for time and keep looking for ways by asking for help from Father Friar Lawrence. This form of fatherhood also made Capulet had more will for his family members by ordering his wife to bring Juliet to him to talk about his wedding day with Paris. In fact, this was shown in Paris because he did not want to feel like he was unable to lead his family, so Capulet accelerated his daughter's marriage.

Data 19

JULIET Is there no pity sitting in the clouds,

That sees into the bottom of my grief?

${ }^{19} \mathrm{O}$, sweet my mother, cast me not away!

Delay this marriage for a month, a week;

Or, if you do not, make the bridal bed

In that dim monument where

Tybalt lies.
LADY CAPULET Talk not to me, for I'll not speak a word:

Do as thou wilt, for I have done with thee. (III.V.233-240)

Juliet, who had almost felt desperate with her husband, then asked her mother to delay the time of her marriage to Paris. However, Lady Capulet felt that she did not have any power over her husband so she could not help Juliet to follow what her daughter offered. Because the great power is from the man who is a father.

Data 20

JULIET ${ }^{20}$ Tell me not, friar, that thou hear'st of this,

Unless thou tell me how I may prevent it:

If, in thy wisdom, thou canst give no help,

Do thou but call my resolution wise, And with this knife I'll help it presently.

God join'd my heart and Romeo's, thou our hands;

And ere this hand, by thee to Romeo seal'd,

Shall be the label to another deed,

Or my true heart with treacherous revolt

Turn to another, this shall slay them both:

Therefore, out of thy longexperienced time,

Give me some present counsel, or, behold,

'Twixt my extremes and me this bloody knife

Shall play the umpire, arbitrating that

Which the commission of thy years and art 
Vol. 2 No. 2

December 2020

e- ISSN 2685 - 0559

p- ISSN 2684 - 673X

Could to no issue of true honour bring.

Be not so long to speak; I long to die,

If what thou speak'st speak not of remedy. (IV.I.58-85)

In the quotation, Juliet who was already confused. She went to Friar Lawrence and asked for his help, but at that time, Paris was talking about her wedding day with Juliet which would be held on Thursday. In this situation, Juliet asked Friar Lawrence for help to cancel the marriage. Even Juliet said that she was willing to die as long as she was not married to Paris.

\section{CONCLUSION}

Romeo and Juliet's drama showed how the condition of women in a patriarchal environment. Juliet became a victim of the dominance of a father who wanted her to marry the man of his choice. Not only in the house, she also became an object contested by men including Paris and Romeo. Patriarchal society believed that the position of men, especially fathers in a family, has power over his family members. This had an impact on women's rights which were limited by this form of power. Moreover, this then made the women hegemony with patriarchal culture so that women unwittingly followed and considered it to be fairness.

Every human being has their own rights and desires, respecting each other about opinions or rights is a matter that is highly recommended. There is no more oppression especially women. Women can also choose their rights and do what they want. Just as a woman can make decisions, she can also become a worker, a leader and an entrepreneur. However, it does not mean that women are able to do all forms of the field, women also have to respect men especially when they have become a wife.

\section{REFERENCES}

Avei, N. (2016). Forbidden Love of Shakespeare's Romeo and Juliet and Fuzûlî's Layla and Majnun. International Journal of Literature and Arts, 4(1-4). Retrieved from https://doi.org/10.11648/j.ijla.s.201604 0101.11

Bucholtz, M. (2014). The feminist foundations of language, gender, and sexuality research. California: John Wiley \&Sons, Ltd.

Cameron, D. (2018). Feminism. London: Profil books Ltd.

Das, P. (2012). Shakespeare, s Representation of women in his tragedies, Prime University Journal, 6(2), 37-56. Retreived from http://www.primeuniversity.edu.bd/07 0513/journals/v_6_n_2_J_D_2012/cont ents_pdf/04_Prime_University.pdf de Beauvoir, S. (1986). The second sex. New York: Vintage Book.

Jajja, M. A. (2014). A feminist reading of Shakespearean tragedies: frailty, thy name is woman, Pakistan Journal of Commerce and Social Sciences, 8(1), 228-237. Retrieved from http://www.jespk.net/publications/171. pdf

Jenainati, C., \& Groves, J. (2007). Introducing feminism. United Kingdom: Icon Books Ltd

Ratna, N. K. (2012). Teori, metode, dan teknik penelitian sastra. Yogyakarta: Pustaka Pelajar. 
Vol. 2 No. 2

December 2020

e- ISSN 2685 - 0559

Sugiyono. (2013). Metodelogi penelitian kuantitatif, kualitatif dan R\&D. Bandung: Alfabeta.

Tyson, L. (2006). Feminist criticism. in critical theory today: a user-friendly guide $\left(2^{\text {th }}\right.$ ed). New York: Routledge.

Walby, S. (1990). Theorizing patriarchy. Oxford: Library of Congress Catalogue. 
Vol. 2 No. 2

December 2020

e- ISSN 2685 - 0559

p- ISSN 2684 - 673X

\section{Jusnal}

IdeBahasa

Inspirasi Dosen Babasa dan Sastra 